\title{
Pemberian Pupuk Kompos Solid Plus (Kos Plus) dan Pupuk NPK Mutiara 16:16:16 terhadap Pertumbuhan dan Produksi Cabai Merah (Capsicum annum L.)
}

\author{
Frikles Gultom*, Chairil Ezward, Seprido \\ Fakultas Pertanian, Universitas Islam Kuantan Singingi \\ *gultomfrikles@gmail.com
}

\begin{abstract}
Abstrak. Penelitian ini bertujuan untuk mengetahui pengaruh pemberian Pupuk Kosplus dan Pupuk NPK Mutiara 16:16:16 terhadap pertumbuhan dan produksi Cabai Merah (Capsicum annum. L), baik secara tunggal maupun interaksi. Metode penelitian yang digunakan adalah Rancangan Acak Kelompok (RAK) Faktorial yang terdiri dari 2 faktor, yaitu S (Pupuk Kosplus) terdiri dari S0 (kontrol), S1 (Pupuk Kosplus 1,68 kg/plot), S2 (Pupuk Kosplus 3,36 kg/plot), S3 (Pupuk Kosplus 5,04 kg/tanaman). Faktor kedua terdiri dari P0 (kontrol), P1 (pupuk NPK 16:16:16 5,25 g/tanaman), P2 (pupuk NPK Mutiara 16:16:16 10,50 g/tanaman), P3 (pupuk NPK Mutiara 16:16:16 15,75 g/tanaman. Hasil penelitian menunjukkan bahwa Perlakuan Pupuk Kosplus secara tunggal memberikan pengaruh yang nyata terhadap tinggi tanaman, jumlah buah, berat buah. Berdasarkan kesimpulan perlakuan terbaik pada tinggi tanaman adalah S1 $(92,86)$, jumlah buah S2 $(351,76)$ dan berat buah S2 (125,56). Sedangkan pupuk NPK Mutiara 16:16:16 secara tunggal memberikan pengaruh nyata pada jumlah buah dengan perlakuan terbaik pada P3 (126,61). Secara interaksi pemberian pupuk kosplus dan pupuk NPK Mutiara 16:16:16 tidak memberikan pengaruh nyata.
\end{abstract}

Kata Kunci: cabai merah, pupuk, kosplus, NPK Mutiara 16:16:16

\section{PENDAHULUAN}

Cabai merah merupakan salah satu jenis sayuran yang cukup penting di Indonesia, baik sebagai komoditas yang dikonsumsi di dalam negeri maupun sebagai komoditas ekspor. Sebagai sayuran, cabai merah selain memiliki nilai gizi yang cukup tinggi, juga mempunyai nilai ekonomi tinggi (Harpenas dan Dermawan, 2010).

Cabai selain sebagai penyedap rasa masakan, juga sebagai sumber vitamin (vitamin A, B1, dan C), protein, karbohidrat, lemak, kalsium, fosfor dan besi, serta mengandung senyawa koloid, capsaicin, flavonoid, dan minyak esensial, cabai berfungsi juga sebagai pembersih paru-paru, pengobatan bronchitis, masuk angin, sinusitis, influenza, reumatik dan asma (Setiadi, 2008).

Data produksi cabai di Kabupaten Kuantan Singingi pada tahun 2011 sebesar 352,9 ton dengan luas lahan 113 ha, produktivitas rata-rata 3,1 ton/ha, pada tahun 2012 produksi cabai sebesar 373.43 ton dengan luas lahan 88 ha, produktivitas rata-rata 4,2 ton/ha, pada tahun 2013 mengalami kenaikan produksi sebesar 484,60 ton dengan luas lahan 102 ha dengan produktivitas 4,74 ton/ha (Dinas Tanaman Pangan Kabupaten Kuantan Singingi, 2013).

Jika dibandingkan dengan produktivitasnya produksi cabai merah di Kabupaten Kuantan Singingi masih tergolong rendah. Hal ini di sebabkan oleh beberapa faktor seperti teknik budidaya dan kesuburan tanah sebagai media tumbuh. Berdasarkan data Dinas Tanaman Pangan (2013), secara umum jenis tanah di Kabupaten Kuantan Singingi adalah Podsolik Merah Kuning (PMK) atau tanah ultisol. Tanah ultisol sering diidentikan tanah yang tidak subur, tetapi sesungguhnya dapat di manfaatkan sebagai lahan pertanian yang potensial, asalkan dilakukan pengolahan yang memperhatikan permasalahan yang ada. Menurut Prasetyo dan Suriadikarta (2006), beberapa permasalahan yang umum pada tanah ultisol adalah kemasaman tanah yang tinggi, $\mathrm{pH}$ rata-rata < 4,50, kejenuhan $\mathrm{Al}$ yang tinggi, miskin hara makro terutama $\mathrm{P}, \mathrm{K}, \mathrm{Ca}, \mathrm{Mg}$, serta kandungan bahan organik yang rendah.

To cite this article: Gultom, F., C. Ezward, dan Seprido. 2019. Pemberian Pupuk Kompos Solid Plus (Kos Plus) dan Pupuk NPK Mutiara 16:16:16 terhadap Pertumbuhan dan Produksi Cabai Merah (Capsicum annum L.). Unri Conference Series: Agriculture and Food Security 1: 210-219. https://doi.org/10.31258/unricsagr.1.a27 
Upaya yang dapat dilakukan untuk meningkatkan kesuburan tanah yaitu dengan menambahkan kandungan bahan organik pada tanah PMK yaitu dengan menambahkan pupuk kompos. Pupuk kompos adalah pupuk yang dihasilkan berasal dari penguraian sisa tumbuhan maupun hewan, ataupun yang berasal dari sisa pengolahan limbah pertanian salah satunya kompos solid plus.

Solid adalah sisa (limbah) dari pengolahan kelapa sawit. Potensi solid di Kabupaten kuantan Singingi sangat besar. Karena banyak terdapat Pabrik Kelapa sawit. Menurut Dinas Pertanian Kabupaten Kuantan Singingi (2016) luas lahan Kelapa Sawit mencapai 130.486 .98 ha dan produksi CPO 464.470,85 ton.

Menurut laporan Dinas Perkebunan Kabupaten Kuantan Singingi (2015) Pabrik Kelapa Sawit (PKS) dengan kapasitas olah mencapai 60 ton/jam dapat menghasilkan limbah cair pabrik kelapa sawit sebanyak 241.200 ton serata menghasilkan solid sebanyak 2,4 ton. Dengan jumlah yang sangat besar ini jika tidak dikelola dengan baik maka akan menyebabkan pencemaran lingkungan, dan apabila di kelola dengan baik akan memiliki dampak positif yang cukup besar.

Secara umum Solid memiliki kandungan unsur hara seperti N, P, K, Mg dan Ca. Utomo dan Widjaja (2005) menyatakan bahwa padatan solid memiliki kandungan bahan kering 81,65\% yang didalamnya terdapat protein kasar 12,63\%; serat kasar 9,98\%; lemak kasar 7,12\%; kalsium $0,03 \%$; fosfor $0,003 \%$; hemiselulosa 5,25\%; selulosa 26,35\% dan energy $3.454 \mathrm{kkal} / \mathrm{kg}$. Untuk meningkatkan kadar unsur hara maka perlu penambahan kotoran ayam, abu janjang serta dolomit dalam pembuatan pupuk kompos solid plus (Kos Plus).

Selain penggunaan Pupuk kompos solid plus (Kos Plus) untuk memperbaiki kesuburan lahan, dapat juga menggunakan pupuk anorganik, seperti pupuk NPK Mutiara 16:16:16. Menurut Novizan (2007), manfaat pupuk NPK Mutiara 16:16:16 adalah menjadikan daun tanaman lebih hijau segar dan banyak mengandung butiran hijau daun yang penting bagi proses fotosintesis mempercepat pertumbuhan tanaman, mempercepat pencapaian tinggi tanaman maksimum dan dalam jumlah anakan maksimum, memacu pertumbuhan akar, perakaran lebih lebat sehingga tanaman menjadi sehat dan kuat, menjadikan batang lebih tegak, kuat, dan mengurangi resiko rebah, meningkatkan daya tahan terhadap serangan hama penyakit tanaman dan kekeringan memacu pembentukan bunga mempercepat pemasakan biji sehingga panen lebih cepat, menambah kandungan protein, memperlancar proses pembentukan gula dan pati, memperbesar ukuran buah serta butir biji dan meningkatkan ketahanan hasil selama pengangkutan dan penyimpanan. Pupuk ini baik digunakan sebagai pupuk awal maupun sebagai pupuk sususlan saat tanaman memasuki fase generatif.

Berdasarkan uraian diatas penulis telah melakukan penelitian dengan judul "Pengaruh Pemberian Pupuk Kompos Solid Plus (KosPlus) dan Pupuk NPK Mutiara (16:16:16) Terhadap Pertumbuhan dan Produksi Cabai Merah (Capsicum annum. L)".

Penelitian ini bertujuan penelitian ini adalah untuk mengetahui Pengaruh Pemberian Pupuk Kompos Solid Plus (Kos Plus) dan Pupuk NPK Mutiara (16:16:16) baik secara tunggal maupun secara interaksi terhadap pertumbuhan dan produksi cabai merah (Capsicum annum. L).

\section{METODE}

Penelitian ini dilaksanakan dengan menggunakan metode survei yang dilaksanakan di Desa Pulau Aro Kecamatan Kuantan Tengah Kabupaten Kuantan Singingi. Pemilihan lokasi penelitian ini didasarkan pada pertimbangan bahwa Penetapan daerah penelitian ini dilakukan secara sengaja dengan pertimbangan bahwa lokasi tersebut merupakan sentaral produksi kerupuk ubi kayu. Penelitian ini telah dilaksanakan dari bulan April sampai bulan Juli 2018.

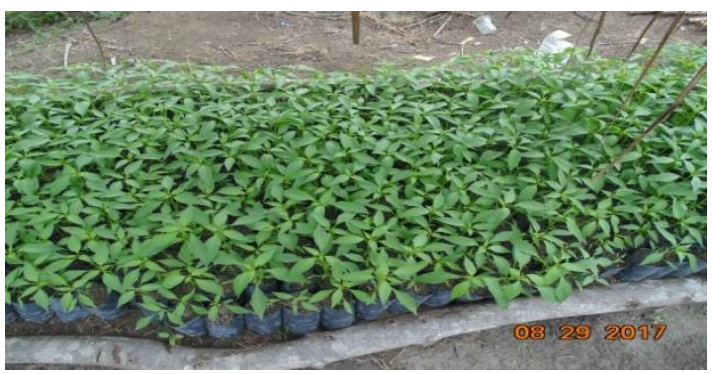

Gambar 1. Umur Bibit Cabe 14 HSS 
Bahan yang digunakan dalam penelitian ini adalah benih Cabai merah varietas Lado F1, pupuk kosplus, pupuk NPK Mutiara (16:16:16), paket pestisida (Rayden 200 EC, Winder 100 EC dan Samite 135 EC), glumon, dolomit, paku, cat, dithane M-45, furadan, label, polybag dan ajir. Sedangkan alatnya adalah cangkul, parang, solo/semprot, martil, timbangan, gembor, meteran, ember, handspayer, kamera, pena, spidol dan kertas HVS.

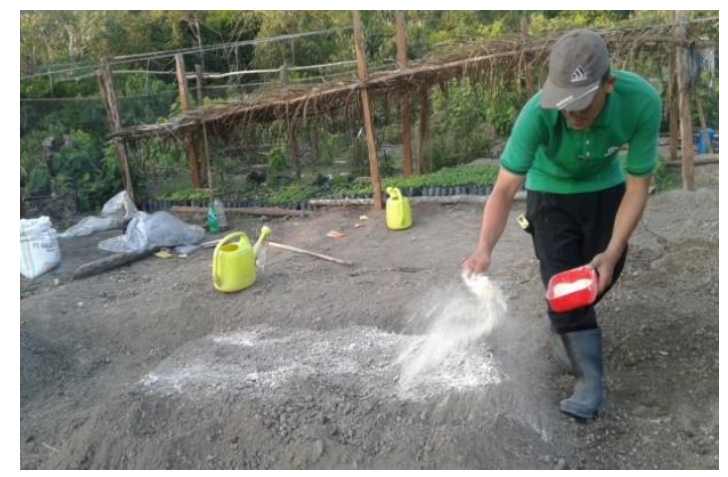

Gambar 2. Pemberian Dolomit

Rancangan yang digunakan dalam penelitian ini adalah Rancangan Acak Kelompok (RAK) Faktorial yang terdiri dari 2 faktor yaitu S (Pupuk Kompos Solid Plus) dan P ( Pupuk NPK Mutiara 16:16:16), masingmasing terdiri dari 4 taraf perlakuan.

Faktor S adalah Pemberian Pupuk kompos solid plus (Kosplus) yang terdiri dari:

S0 :Tanpa pemberian pupuk kosplus

S1 :Pemberian pupuk kosplus 10 ton/ha setara $1,68 \mathrm{~kg} /$ plot

S2 :Pemberian pupuk kosplus 20 ton/ha setara 3,36 kg / plot

S3 :Pemberian pupuk kosplus 30 ton/ha setara 5,04 kg / plot

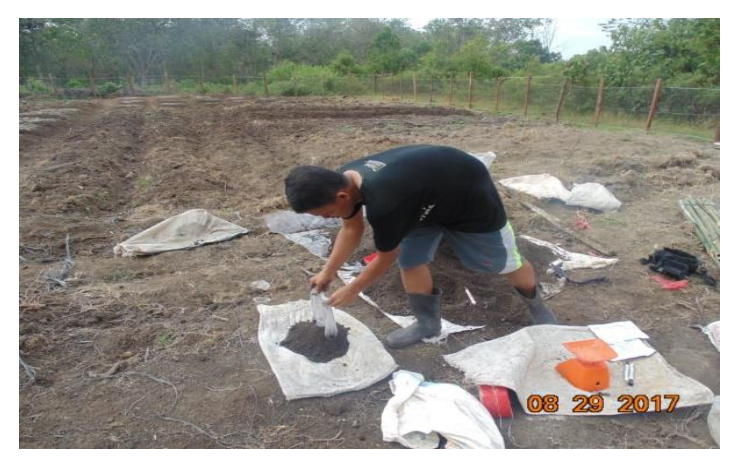

Gambar 3. Perlakuan Kosplus

Faktor P adalah Pemberian Pupuk NPK

P0 : Tanpa pemberian pupuk NPK

P1 : Pemberian pupuk NPK $125 \mathrm{~kg} / \mathrm{ha}$ setara $5,25 \mathrm{gr} / \mathrm{tanaman}$

P2 : Pemberian pupuk NPK $250 \mathrm{~kg} / \mathrm{ha}$ setara $10,50 \mathrm{gr} / \mathrm{tanaman}$

P3 : Pemberian pupuk NPK $375 \mathrm{~kg} / \mathrm{ha}$ setara 15,75 gr/tanaman

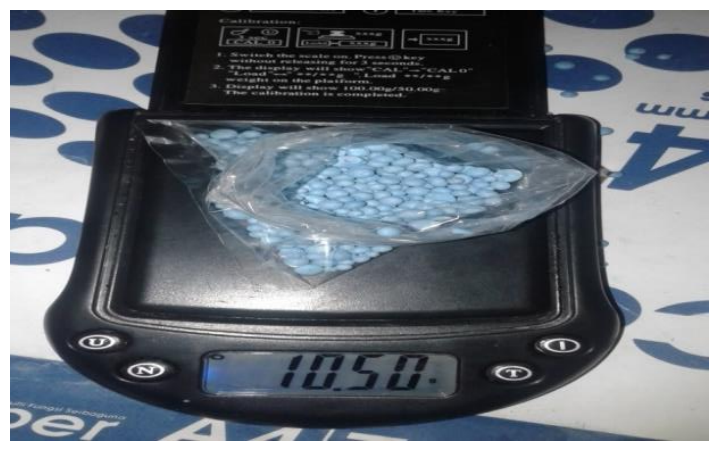


Gambar 4. Penimbangan NPK

Dengan demikian terdapat 16 kombinasi perlakuan dan masing-masing terdiri dari 3 ulangan sehingga didapat 48 plot, dalam satu plot terdiri dari 4 tanaman, 3 tanaman dijadikan tanaman sampel. Jumlah tanaman keseluruhannya adalah 192 tanaman.

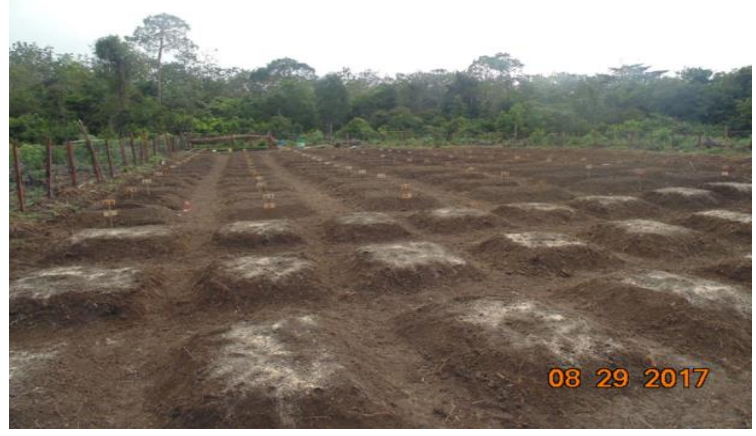

Gambar 5. Lahan Penelitian

$$
Y i j k=\mu+\rho i+a j+\beta k+(a \beta) j k+\varepsilon i j k
$$

Keterangan:

Yijk = Hasil pengamatan blok ke-i dengan perlakuan pupuk kosplus pada taraf ke- $\mathrm{j}$ dan pupuk NPK Mutiara 16:16:16 pada taraf ke- $\mathrm{k}$

$\mu \quad=$ Nilai tengah perlakuan

$\mathrm{i} \quad=$ Pengaruh blok ke- $\mathrm{i}$

aj $\quad=$ Pengaruh pupuk kosplus pada taraf ke- $\mathrm{j}$

$\beta \mathrm{k} \quad=$ Pengaruh pupuk NPK mutiara pada taraf ke- $\mathrm{k}$

(aß) jk = Pengaruh interaksi antara pupuk kosplus pada taraf ke-j dan pupuk NPK mutiara pada taraf ke-k عijk = Pengaruh galat percobaan blok ke- $\mathrm{i}$ yang mendapat perlakuan pupuk kosplus ke-j dengan pupuk NPK mutiara ke- $\mathrm{k}$.

\section{HASIL DAN PEMBAHASAN}

\section{Tinggi Tanaman $(\mathbf{c m})$}

Data hasil pengamatan terhadap tinggi tanaman cabai merah setelah dianalisis secara statistik dan hasil analisis sidik ragam memperlihatkan bahwa Perlakuan Pupuk Kosplus secara tunggal memberikan pengaruh yang nyata terhadap tinggi tanaman, sedangkan perlakuan Pupuk NPK Mutiara 16:16:16 secara tunggal memberikan pengaruh yang tidak nyata terhadap tinggi tanaman. Secara interaksi Perlakuan Pupuk Kosplus dan Pupuk NPK Mutiara 16:16:16 memberikan pengaruh yang tidak nyata terhadap tinggi tanaman. Rata rata tinggi tanaman setelah diuji dengan BNJ pada taraf 5\% dapat dilihat pada Tabel 1.

Tabel 1 menunjukkan bahwa perlakuan pupuk kosplus secara tunggal memberikan pengaruh yang nyata terhadap tinggi tanaman, Perlakuan terbaik terdapat pada perlakuan $S 1(10 \mathrm{ton} / \mathrm{ha})$ yaitu $92,86 \mathrm{~cm}$, tidak berbeda nyata dengan perlakuan S2 (20 ton/ha) yaitu 92,72 cm dan S3 (30 ton/ha) yaitu 91,73 cm, tetapi berbeda nyata dengan perlakuan S0 (tanpa perlakuan) yaitu 76,33 cm. Pemberian pupuk kosplus dengan dosis 10 ton/ha dapat menghasilkan tinggi tanaman yang maksimal pada penelitian ini dan setelah dibandingkan dengan deskripsi $(90-100 \mathrm{~cm})$ maka hasil yang di peroleh telah mencapai deskripsi.

Berdasarkan Tabel 1 perlakuan terbaik terdapat pada perlakuan S1, hal ini dikarenakan pemberian pupuk kosplus dengan dosis 10 ton/ha dapat meningkatkan kesuburan tanah. Pupuk kosplus mengandung bahan organik yang berperan penting memperbaiki sifat fisika tanah. Bahan organik tersebut dapat membantu pembentukan agregat, struktur tanah dan mempermudah penyerapan unsur hara.tetapi jumlah tiap jenis unsur hara tersebut rendah walaupun kandungan bahan organik di dalamnya sangatlah tinggi. Hal ini sesuai dengan pendapat Hanafiah (2012), bahwa secara fisik bahan organik dapat memperbaiki struktur tanah, secara kimia akan menyumbangkan hara makro serta mikro, dan secara biologi meningkatkan aktivitas organisme dalam tanah. 
Tabel 1. Rata-Rata Tinggi Tanaman $(\mathrm{cm})$ Tanaman Cabai Merah dengan Perlakuan Pupuk Kosplus dan Pupuk NPK Mutiara 16:16:16 (umur 129 hari setelah semai)

\begin{tabular}{cccccc}
\hline \multirow{2}{*}{$\begin{array}{c}\text { Faktor S } \\
\text { (Pupuk Kosplus) }\end{array}$} & \multicolumn{3}{c}{ Faktor P (Pupuk NPK Mutiara 16 16 16 ) } & \multirow{2}{*}{ Rerata S } \\
\cline { 2 - 5 } S0 & 72,22 & 70,89 & 79,67 & 82,55 & $76,33 \mathrm{~b}$ \\
S1 & 82,44 & 97,56 & 89,33 & 102,11 & $92,86 \mathrm{a}$ \\
S2 & 92,67 & 94,33 & 93,00 & 90,89 & $92,72 \mathrm{a}$ \\
S3 & 89,57 & 88,22 & 89,11 & 100,00 & $91,73 \mathrm{a}$ \\
\hline Rarata P & 84,23 & 87,75 & 87,78 & 93,89 & \\
\hline \multicolumn{7}{c}{ KK $=12,71 \%$ BNJ S= 11,64 } \\
\hline
\end{tabular}

Angka-angka pada baris dan kolom yang diikuti oleh huruf kecil yang sama adalah tidak berbeda nyata menurut uji lanjut (BNJ) pada taraf 5\%

Salah satu unsur hara yang dapat mempengaruhi tinggi tanaman adalah unsur hara Nitrogen. Menurut Okalia, Ezward dan Haitami (2017), Pupuk kosplus mengandung Nitrogen 2,1\%. Menurut Sanchez (1992), mengatakan bahwa salah satu faktor yang mempengaruhi pertumbuhan awal tanaman adalah kecukupan unsur hara $\mathrm{N}$, apabila unsur hara $\mathrm{N}$ tercukupi maka pertumbuhan tanaman akan lebih baik. Tinggi tanaman merupakan perkembangan vegetatif taanaman, yang mana dipengaruhi oleh unsur hara $\mathrm{N}$, apabila kekurangn nitrogen maka pembentukan klorofil akan terganggu.

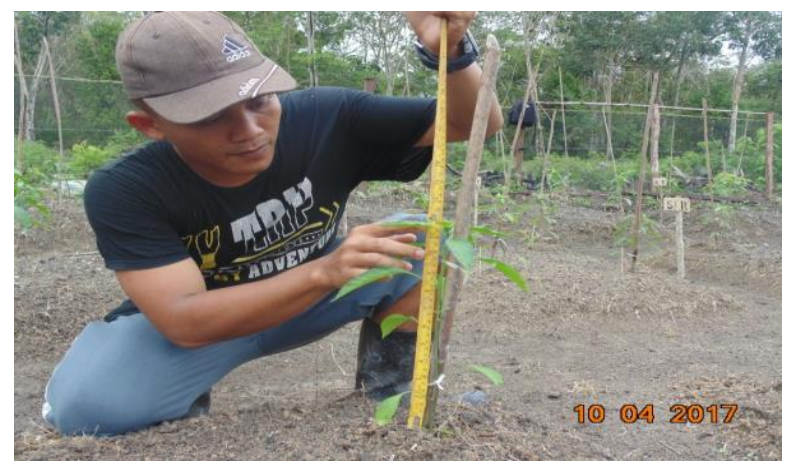

Gambar 6. Pengukuran Tinggi Tanaman

Setelah diamati perlakuan S2 dan S3 pertumbuhan tanaman justru lebih rendah dibandingkan perlakuan $\mathrm{S} 1$, hal ini dikarenakan kosplus yang bahan baku utamanya adalah solid yang memiliki partikel-partikel halus, mengakibatkan pori-pori pada tanah tertutup dan menjadi padat. Kondisi ini tidak menguntungkan bagi akar untuk tumbuh dan berkembang, sehingga penyerapan unsur hara yang ada menjadi terhambat.

Tidak berpengaruh nyatanya perlakuan pemberian pupuk NPK Mutiara 16:16:16 terhadap tinggi tanaman karena dosis pupuk yang diberikan intervalnya masih rendah sehingga tidak berpengaruh terhadap tinggi tanaman, meski dosis yang diberikan bervariasi, namun demikian bila dilihat dari hasil pengukuran tinggi tanaman umur 129 HSS, maka pemberian pupuk NPK Mutiara 16:16:16 dengan dosis $375 \mathrm{~kg} / \mathrm{ha}$ setara 15,75 gr/tanaman (P3) menghasilkan tinggi tanaman yang paling baik dibandingkan perlakuan lainnya. Selain itu tidak berpengaruhnya pupuk NPK Mutiara 16:16:16 karena faktor lingkungan.

Berdasarkan Tabel 1 secara interaksi menunjukan tidak memberikan pengaruh nyata terhadap tinggi tanaman. Kombinasi perlakuan terbaik terdapat pada S1P3 dengan tinggi tanaman 102,11 cm, sedangkan perlakuan terendah terdapat pada S0P1 dengan tinggi tanaman 70,89 $\mathrm{cm}$. Tidak berpengaruh nyata terhadap pada setiap perlakuan disebabkan jenis pupuk yang diberikan memiliki kandungan yang hampir sama, yaitu termasuk pupuk majemuk yang mengandung banyak hara yang dibutuhkan bagi pertumbuhan tinggi tanaman.

\section{Umur Muncul Bunga (HSS)}

Data hasil pengamatan terhadap Umur muncul bunga dianalisis secara statistik dan hasil analisis sidik ragam memperlihatkan bahwa Perlakuan Pupuk Kosplus dan perlakuan Pupuk NPK Mutiara 16:16:16, baik secara tunggal maupun interaksi memberikan pengaruh yang tidak nyata terhadap umur muncul bunga. Rata - rata tinggi tanaman setelah diuji dengan BNJ pada taraf 5\% dapat dilihat pada tabel 2. 
Tabel 2. Rata-Rata Umur muncul bunga (HSS) Tanaman Cabai Merah dengan Perlakuan Pupuk Kosplus dan Pupuk NPK Mutiara 16:16:16

\begin{tabular}{cccccc}
\hline Faktor S & \multicolumn{3}{c}{ Faktor P (Pupuk NPK Mutiara 16 16 16) } & \multirow{2}{*}{ Rerata S } \\
\cline { 2 - 5 } (Pupuk Kosplus) & P0 & P1 & P2 & P3 & \\
\hline S0 & 42,00 & 42,00 & 42,00 & 42,00 & 42,00 \\
S1 & 42,00 & 42,00 & 42,00 & 43,67 & 42,42 \\
S2 & 42,00 & 42,00 & 42,00 & 42,00 & 42,00 \\
S3 & 42,00 & 42,00 & 43,67 & 43,67 & 42,83 \\
\hline Rata-rata P & 42,00 & 42,00 & 42,42 & 42,83 & \\
KK=2,75\% & & & & & \\
\hline
\end{tabular}

Tabel 2. menujukkan bahwa perlakuan pupuk kosplus tidak memberikan pengaruh nyata terhadap umur muncul bunga, terlihat pada perlakuan S0 (tanpa pupuk kosplus) dan pemberian pupuk kosplus 3,36 kg/plot (S2) menunjukan umur muncul bunga tercepat diantara umur muncul bunga lainnya, yaitu 42,00 HSS. umur muncul bunga terlama yaitu pada pemberian pupuk kosplus sebanyak 5,04 kg/plot (S3) diperoleh hasil yaitu 42,83 HSS.

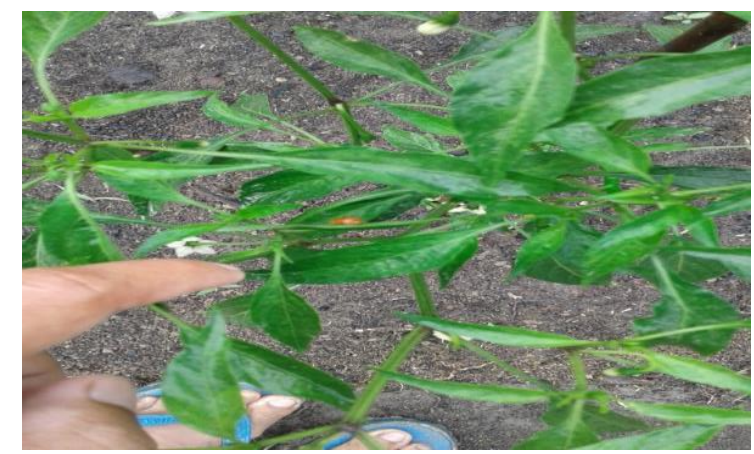

Gambar 7. Pengamatan Umur Berbunga

Tabel 2. menujukkan bahwa perlakuan NPK Mutiara 16:16: tidak memberikan pengaruh nyata terhadap umur muncul bunga, terlihat pada perlakuan P0 (tanpa pupuk NPK Mutiara 16:16:16) dan pemberian pupuk NPK Mutiara 16:16:16 10,50 gr/tanaman (P2) menunjukan umur muncul bunga tercepat diantara umur muncul bunga lainnya, yaitu 42,00 HSS. Umur muncul bunga terlama yaitu pada pemberian pupuk NPK Mutiara 16:16:16 sebanyak 15,75 gr/tanaman (P3) diperoleh hasil yaitu 42,83 HSS. Bahwa tidak terjadinya perbedaan antar sesama perlakuan bisa disebabkan karena faktor lingkungan dan genetik yang mempengaruhi umur berbunga tersebut seperti tanah dan iklim, perubahan ini mencerminkan pemicu dari kelompok gen tertentu yang berperan dalam proses pembungaan. Menurut Lakitan (2012), Tanaman akan menghasilkan bunga bila zat cadangan terpenuhi dan ditentukan juga oleh sifat tanaman serta faktor lingkungan.

Tabel 2. menujukkan bahwa perlakuan interaksi antara pupuk kosplus dan pupuk NPK Mutiara 16:16:16 tidak memberikan pengaruh nyata terhadap umur muncul bunga, terlihat pada perlakuan S0P0, S0P1, S0P2, S0P3, S1P0, S1P1, S1P2, S2P0, S2P1, S2P2, S2P3, S3P0 dan S3P1, menunjukan umur muncul bunga tercepat diantara umur muncul bunga lainnya, yaitu 42,00 Hss umur muncul bunga terlama yaitu pada pemberian pupuk kosplus dan pupuk NPK Mutiara 16:16:16 pada perlakuan S1P3, S3P2 dan S3P3 diperoleh hasil yaitu 43,67 Hss. Tidak terjadinya pengaruh perlakuan interaksi antara pupuk kosplus dan pupuk NPK Mutiara 16:16:16 disebabkan oleh jarak atau range antar perlakuan dan sifat genetik, dimana varietas yang digunakan adalah Lado F1. Islami dan Utomo (1995), menyatakan hasil maksimum suatu tanaman ditentukan oleh potensi genetik tanaman dan kemampuannya dalam beradabtasi dengan lingkungan akan lebih baik tumbuhnya bila dibandingkan dengan tanaman yang tidak mempunyai kemampuan dalam beradabtasi.

\section{Umur Panen (HSS)}

Data hasil pengamatan terhadap umur panen dianalisis secara statistik dan hasil analisis sidik ragam memperlihatkan bahwa Perlakuan Pupuk Kosplus dan perlakuan Pupuk NPK Mutiara 16:16:16, baik secara 
tunggal maupun interaksi memberikan pengaruh yang tidak nyata terhadap umur panen. Rata - rata umur panen setelah diuji dengan BNJ pada taraf 5\% dapat dilihat pada Tabel 3.

Tabel 3. Rata-Rata Umur Panen (HSS) Tanaman Cabai Merah dengan Perlakuan Pupuk Kosplus dan Pupuk NPK Mutiara 16:16:16

\begin{tabular}{cccccc}
\hline Faktor S & \multicolumn{3}{c}{ Faktor P (Pupuk NPK Mutiara 16 16 16) } & \multirow{2}{*}{ Rerata S } \\
\cline { 2 - 5 } (Pupuk Kosplus) & P0 & P1 & P2 & P3 & \\
\hline S0 & 66,56 & 67,89 & 68,33 & 69,22 & 68,00 \\
S1 & 66,11 & 66,11 & 66,11 & 66,11 & 66,11 \\
S2 & 65,22 & 63,89 & 67,00 & 66,11 & 65,56 \\
S3 & 65,67 & 66,56 & 67,44 & 66,11 & 66,45 \\
\hline Rata-rata P & 65,89 & 66,11 & 67,22 & 66,89 & \\
\hline
\end{tabular}

$\mathrm{KK}=2,75$

Tabel 3 menujukkan bahwa perlakuan pupuk kosplus tidak memberikan pengaruh nyata terhadap umur panen, terlihat pada perlakuan S2 pemberian pupuk kosplus sebanyak 3,36 kg/plot menunjukan umur panen tercepat diantara umur panen lainnya, yaitu 65,56 HSS. Umur panen terlama yaitu tanpa pemberian pupuk kosplus (S0) diperoleh hasil yaitu 68,00 HSS. Hal ini disebabkan oleh varietas yang digunakan yaitu Lado F1 serta range yang digunakan dalam penelitian masih terlalu dekat. Dimana menurut Sumarno (1991) menyatakan bahwa cepat atau lambatnya tanaman di panen di pengaruhi oleh banyak faktor antara lain sifat genetika tanaman, temperatur, curah hujan dan intensitas cahaya yang diterima oleh tanaman.

Tabel 3 menujukkan bahwa perlakuan NPK Mutiara 16:16:16 tidak memberikan pengaruh nyata terhadap umur panen, terlihat pada perlakuan P0 (tanpa pupuk NPK Mutiara 16:16:16) dan pemberian pupuk NPK Mutiara 16:16:16 10,50 gr/tanaman (P2) menunjukan umur panen tercepat diantara umur panen lainnya, yaitu 42,00 HSS. Umur panen terlama yaitu pada pemberian pupuk NPK Mutiara 16:16:16 sebanyak 15,75 gr/tanaman (P3) diperoleh hasil yaitu 42,83 HSS. Hal ini menunjukkan bahwa umur panen lebih di pengaruhi oleh faktor genetik dan faktor lingkungan. Menurut Mangoendidjojo (2000), penampilan suatu tanaman pada lingkungan tertentu merupakan hasil interaksi faktor lingkungan dan genetik. Dalam hal ini faktor genetik lebih dominan mempengaruhi umur panen dibandingkan dengan faktor lingkungan.

Tabel 3 menujukkan bahwa perlakuan interaksi antara pupuk kosplus dan pupuk NPK Mutiara 16:16:16 tidak memberikan pengaruh nyata terhadap umur panen, terlihat pada perlakuan S2P0 menunjukan umur panen tercepat diantara umur panen lainnya, yaitu 65,22 HSS. Umur panen terlama yaitu pada pemberian pupuk kosplus dan pupuk NPK Mutiara 16:16:16 pada perlakuan S0P3 diperoleh hasil yaitu 69,22 HSS. Tidak terjadinya pengaruh perlakuan interaksi antara pupuk kosplus dan pupuk NPK Mutiara 16:16:16 disebabkan oleh jarak atau range antar perlakuan dan sifat genetik, dimana varietas yang digunakan adalah Lado F1. Menurut Sunarto (1997), bahwa faktor genetik mengontrol umur tanaman melalui susunan gen dalam kromosomnya, disamping itu faktor lingkungan seperti tanah dan iklim yang mengatur fisiologis.

\section{Jumlah Buah (Buah)}

Data hasil pengamatan terhadap Jumlah buah setelah dianalisis secara statistik dan hasil analisis sidik ragam memperlihatkan bahwa Perlakuan Pupuk Kosplus dan perlakuan Pupuk NPK Mutiara 16:16:16 secara tunggal memberikan pengaruh yang nyata, sedangkan interaksi Perlakuan Pupuk Kosplus dan perlakuan Pupuk NPK Mutiara 16:16:16 secara interaksi memberikan pengaruh yang tidak nyata terhadap umur Jumlah buah. Rata - rata Jumlah buah setelah diuji dengan BNJ pada taraf 5\% dapat dilihat pada Tabel 4.

Tabel 4. Rata-Rata Jumlah Buah (Hss) Tanaman Cabai Merah dengan Perlakuan Pupuk Kosplus dan Pupuk NPK Mutiara 16:16:16

\begin{tabular}{crrrrr}
\hline Faktor S & \multicolumn{3}{c}{ Faktor P (Pupuk NPK Mutiara 16 16 16) } & \multirow{2}{*}{ Rerata S } \\
\cline { 2 - 5 } (Pupuk Kosplus) & \multicolumn{1}{c}{ P0 } & \multicolumn{1}{c}{ P1 } & \multicolumn{1}{c}{ P2 } & \multicolumn{1}{c}{ P3 $n$} & \\
\hline S0 & 58,44 & 63,33 & 73,00 & 96,44 & $72,80 \mathrm{~b}$ \\
S1 & 77,22 & 142,00 & 99,11 & 140,00 & $114,58 \mathrm{a}$ \\
S2 & 125,11 & 106,11 & 135,00 & 136,00 & $125,56 \mathrm{a}$ \\
S3 & 91,11 & 86,22 & 110,22 & 134,00 & $105,39 \mathrm{ab}$ \\
\hline Rarata P & $87,97 \mathrm{~b}$ & $99,42 \mathrm{ab}$ & $104,33 \mathrm{ab}$ & $126,61 \mathrm{a}$ & \\
KK=28,26\% BNJS=32,76 BNJP=32,75 & & & & \\
\hline
\end{tabular}


Angka-angka pada baris dan kolom yang diikuti oleh huruf kecil yang sama adalah tidak berbeda nyata menurut uji lanjut $(\mathrm{BNJ})$ pada taraf $5 \%$

Tabel 4 menunjukkan bahwa perlakuan pupuk kosplus secara tunggal memberikan pengaruh yang nyata terhadap jumlah buah, perlakuan terbaik terdapat pada perlakuan S2 (20 ton/ha) yaitu 125,56 HSS, tidak berbeda nyata dengan perlakuan S1 (10 ton/ha) yaitu 114,58 HSS dan S3 (30 ton/ha) yaitu 105,39 HSS, tetapi berbeda nyata dengan perlakuan S0 (tanpa perlakuan) yaitu 72,80 HSS.

Perlakuan terbaik terdapat pada perlakuan S2 (20 ton/ha) yaitu 125,56 HSS. Hal ini dikarenakan pemberian pupuk kosplus dengan dosis 20 ton perhektar dapat meningkatkan kesuburan tanah. Pupuk kosplus mengandung bahan organik yang berperan penting memperbaiki sifat fisik, kimia dan biologi tanah. Bahan organik tersebut dapat membantu pembentukan agregat, struktur tanah dan mempermudah penyerapan unsur hara. Pupuk kosplus mempunyai komposisi kandungan unsur hara yang lengkap, tetapi jumlah tiap jenis unsur hara tersebut rendah walaupun kandungan bahan organik di dalamnya sangatlah tinggi. Hal ini sesuai dengan pendapat Marsono (2002) pemberian pupuk organik bertujuan untuk memperbaiki sifat fisik, kimia dan biologi tanah serta meningkatkan efisiensi penggunaan pupuk pada tanaman.

Mulyani dan Sutedjo (1998), bahwa untuk pertumbuhan vegetatif dan generatif tanaman diperlukan unsur-unsur hara terutama N, P. Unsur hara N diperlukan untuk pembentukan karbohidrat, protein, lemak dan persenyawaan organik lainnya. Unsur P berperan dalam pembentukan bagian generatif tanaman. Salah satu unsur hara yang dapat mempengaruhi jumlah buah adalah unsur hara Fosfor. Menurut Okalia et al (2017), Pupuk kosplus mengandung Fosfor 1,25\%. Menurut Budi dan Purbasari (2009) bahwa unsur P berfungsi untuk memacu pertumbuhan akar dan pembentukan buah dan biji.

Tabel 4 menunjukkan bahwa perlakuan pupuk NPK Mutiara 16:16:16 secara tunggal memberikan pengaruh yang nyata terhadap jumlah buah, Perlakuan terbaik terdapat pada perlakuan P3 (15,75 g/tanaman) yaitu 126,61, tidak berbeda nyata dengan perlakuan P1 (5,25 g/tanaman) yaitu 99,42 dan P2 (10,50 g/tanaman) yaitu 104,33, tetapi berbeda nyata dengan perlakuan P0 (tanpa perlakuan) yaitu 87,97. Perlakuan terbaik terdapat pada perlakuan P3 (15,75 g/tanaman) yaitu 126,61.

Berpengaruh nyatanya perlakuan pemberian pupuk NPK Mutiara 16:16:16 terhadap jumlah buah, perlakuan terbaik terdapat pada perlakuan P3 (15,75 g/tanaman) yaitu 126,61 HSS, tidak berbeda nyata dengan perlakuan P2 (10,50 g/tanaman) yaitu 104,33 HSS dan P1 (5,25 g/tanaman) yaitu 99,42 HSS, tetapi berbeda nyata dengan perlakuan P0 (tanpa perlakuan) yaitu 87,97.

Perlakuan terbaik terdapat pada perlakuan P3 (15,75 g/tanaman) yaitu 126,61. Hal ini dikarenakan dosis yang telah diberikan mampu meningkatkan hasil terbaik. Pupuk anorganik NPK merupakan pupuk majemuk yang mengandung unsur hara yang makro seperti Nitrogen, Fosfor dan Kalium. Unsur hara tersebut sangat di butuhkan oleh tanaman. Menurut Sutedjo (2002) fungsi dari fosfor dalam tanaman yaitu dapat mempercepat pertumbuhan akar semai serta memperkuat pertumbuhan tanaman mudah menjadi dewasa pada umumnya dan mempercepat pembungaan dan pemasakan buah dan biji.

Berdasarkan Tabel 4 secara interaksi menunjukan tidak memberikan pengaruh nyata terhadap jumlah buah. Kombinasi perlakuan terbaik terdapat pada perlakuan S1P3 yaitu pupuk kosplus dengan dosis 10 ton/ha dan pupuk NPK Mutiara 16:16:16 dengan dosis $375 \mathrm{~kg} / \mathrm{ha}$ setara 15,75 gr/tanaman menghasilkan jumlah buah yang paling baik (140 buah) dibandingkan perlakuan lainnya, sedangkan perlakuan terendah terdapat pada SOP0 dengan jumlah buah 58,44 buah. Tidak berpengaruh nyata terhadap pada setiap perlakuan, hal ini dikarenakan jumlah buah dipengaruhi oleh faktor genetik dan faktor lingkungan. Menurut Rizwan (2010) kombinasi dari dua perlakuan tertentu tidak selamanya memberikan pengaruh yang baik pada tanaman. Kombinasi dari dua perlakuan dapat mendorong, menghambat atau sama sekali tidak memberikan respon terhadap pupuk yang diberikan sangat ditentukan oleh berbagai faktor. Antara lain sifat genetis dari tanaman dan kondisi iklim. Faktor-faktor tersebut tidak berdiri sendiri, melainkan satu sama lain saling berkaitan.

\section{Berat Buah (g/tanaman)}

Data hasil pengamatan terhadap Berat Buah dianalisis secara statistik dan hasil analisis sidik ragam memperlihatkan bahwa Perlakuan Pupuk Kosplus secara tunggal memberikan pengaruh yang nyata terhadap Berat Buah, sedangkan perlakuan Pupuk NPK Mutiara 16:16:16 secara tunggal memberikan pengaruh yang tidak nyata terhadap Berat Buah. Secara interaksi Perlakuan Pupuk Kosplus dan Pupuk NPK Mutiara 16:16:16 memberikan pengaruh yang tidak nyata terhadap Berat Buah. Rata - rata tinggi tanaman setelah diuji dengan BNJ pada taraf 5\% dapat dilihat pada Tabel 10. 
Tabel 5. Rata-Rata Berat Buah (g/tanaman) Tanaman Cabai Merah dengan Perlakuan Pupuk Kosplus dan Pupuk NPK Mutiara 16:16:16

\begin{tabular}{cccccc}
\hline $\begin{array}{c}\text { Faktor S } \\
\text { (Pupuk Kosplus) }\end{array}$ & \multicolumn{4}{c}{ Faktor P (Pupuk NPK Mutiara 16 16 16) } & \multirow{2}{*}{ Rerata S } \\
\cline { 2 - 5 } S0 & P0 & P1 & P2 & P3 & \\
S1 & 157,52 & 165,59 & 186,83 & 282,10 & $198,01 \mathrm{~b}$ \\
S2 & 235,22 & 448,81 & 306,09 & 410,75 & $350,22 \mathrm{a}$ \\
S3 & 389,89 & 309,23 & 402,83 & 305,10 & $351,76 \mathrm{a}$ \\
\hline Rata-rata P & 266,72 & 246,28 & 357,00 & 419,78 & $322,44 \mathrm{ab}$ \\
KK=2,75\% BNJS=134,37 & 262,34 & 292,48 & 313,19 & 354,43 & \\
\hline
\end{tabular}

Angka-angka pada baris dan kolom yang diikuti oleh huruf kecil yang sama adalah tidak berbeda nyata menurut uji lanjut (BNJ) pada taraf 5\%

Tabel 5 menunjukkan bahwa perlakuan pupuk kosplus secara tunggal memberikan pengaruh yang nyata terhadap berat buah, perlakuan terbaik terdapat pada perlakuan S2 (20 ton/ha) yaitu 351,76 g/tanaman, tidak berbeda nyata dengan perlakuan dan S1 (10 ton/ha) yaitu 350,22 g/tanaman dan perlakuan S3 (30 ton/ha) yaitu 322,44 g/tanaman, tetapi berbeda nyata dengan perlakuan S0 (tanpa perlakuan) yaitu 198,01 g/tanaman. Perlakuan terbaik terdapat pada perlakuan S2 (20 ton/ha) yaitu 351,76 g/tanaman. Pemberian pupuk Kosplus dengan dosis 20 ton/ha dapat menghasilkan berat buah pertanaman paling tinggi dibandingkan dengan perlakuan lainnya. Hal ini karena pupuk kosplus yang merupakan pupuk organik dapat meningkatkan kesuburan tanah. Menurut Lingga dan Marsono (2007), mengatakan bahwa pemberian pupuk organik selain dapat memperbaiki sifat kimia tanah, juga dapat memperbaiki sifat fisik dan biologi tanah.

Tidak berpengaruh nyatanya perlakuan pemberian pupuk NPK Mutiara 16:16:16 terhadap berat buah karena dosis pupuk yang diberikan intervalnya masih rendah, sehingga tidak berpengaruh terhadap berat buah, meski dosis yang diberikan bervariasi, namaun demikian bila dilihat dari hasil pengamatan berat buah, maka pemeberian pupuk NPK Mutiara 16:16:16 dengan dosis $375 \mathrm{~kg} / \mathrm{ha}$ setara 15,75 gr/tanaman (P3) menghasilkan berat buah yang paling baik yaitu 354,43 g dibandingkan perlakuan lainnya. Selain itu tidak berpengaruhnya pupuk NPK Mutiara 16:16:16 karena faktor genetik dan faktor lingkungan.

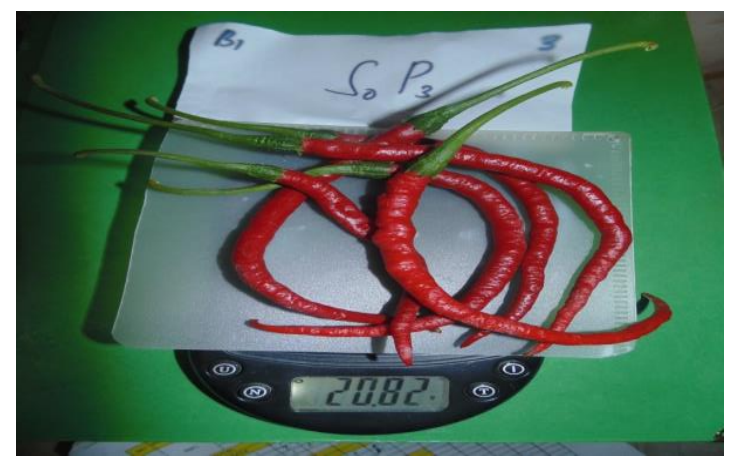

Gambar 8. Penimbangan Berat Buah

Berdasarkan Tabel 5 secara interaksi menunjukan tidak memberikan pengaruh nyata terhadap berat buah. Kombinasi perlakuan terbaik terdapat pada S1P1 dengan berat buah 448,81 g/tanaman, sedangkan perlakuan terendah terdapat pada S0P0 dengan berat buah $157,52 \mathrm{~g} /$ tanaman. Tidak berpengaruh nyata terhadap setiap perlakuan disebabkan jenis pupuk yang diberikan memiliki kandungan yang hampir sama, yaitu termasuk pupuk majemuk yang mengandung banyak hara yang dibutuhkan bagi perkembangan tanaman

\section{KESIMPULAN}

Berdasarkan hasil dan pembahasan di atas maka dapat disimpulkan bahwa:

1. Pemberian perlakuan pupuk kosplus secara tunggal memberikan pengaruh yang nyata terhadap parameter pengamatan tinggi tanaman, Perlakuan terbaik terdapat pada perlakuan $\mathrm{S} 1$ (10 ton/ha) yaitu 92,86 cm, jumlah buah, perlakuan terbaik terdapat pada perlakuan S2 (20 ton/ha) yaitu 125,56, berat buah, Perlakuan terbaik terdapat pada perlakuan S2 (20 ton/ha) yaitu 351,76 g. 
2. Pemberian perlakuan pupun NPK Mutiara 16:16:16 secara tunggal memberikan pengaruh nyata terhadap parameter jumlah buah, Perlakuan terbaik terdapat pada perlakuan P3 (375 kg/ha) yaitu 126,61.

3. Perlakuan secara interaksi pemberian pupuk kosplus dan pupuk NPK Mutiara 16:16:16 tidak berpengaruh nyata terhadap tinggi tanaman, umur berbunga, umur panen, jumlah buah dan tinggi tanaman.

\section{Saran}

Berdasarkan hasil penelitian yang telah dilakukan, maka penggunaan pupuk kosplus sebaiknya pada perlakuan S2 yaitu 20 ton/ha, sementara pada perlakuan pupuk NPK Mutiara 16:16:16 perlu dilakukan penelitian lebih lanjut dengan dosis yang lebih tinggi untuk melihat produksi optimum.

\section{DAFTAR PUSTAKA}

Budi, F. S. dan A. Purbasari. 2009. Pembuatan Pupuk Fosfat dari Batuan Fosfat Alam Secara Acidulasi. Teknik 30(2): 93-97.

Dinas Perkebunan Kabupaten Kuantan Singingi. 2015. Limbah Pabrik Kelapa Sawit (PKS) di Kabupaten Kuantan Singingi.

Dinas Pertanian Kabupaten Kuantan Singingi. 2016. Luas Lahan Kelapa Sawit dan CPO di Kabupaten Kuantan Singingi.

Dinas Tanaman Pangan Kabupaten Kuantan Singingi. 2013. Luas Tanam dan Produksi Cabe di Kabupaten Kuantan Singingi.

Hanafiah, K.A. 2012. Dasar-Dasar Ilmu Tanah. Jakarta: Rajawali Pers.

Harpenas, A., dan R. Dermawan. 2010. Budidaya Cabai Unggul. Jakarta: Penerbit Swadaya.

Islami. T., dan W. H. Utomo. 1995. Hubungan Tanah, Air dan Tanaman. IKIP. Semarang: Press Semarang.

Lakitan. 2012. Dasar-dasar Fisiologi Tumbuhan. Jakarta: Rajawali Press.

Lingga, P dan Marsono. 2007. Petunjuk Penggunaan Pupuk. Jakarta: Penebar Swadaya.

Mangoendidjojo. 2000. Dasar-dasar Pemuliaan Tanaman. Yogyakarta: Kanisius.

Marsono. 2002. Petunjuk Penggunaan Pupuk. Jakarta: Penebar Swadaya.

Mulyani. Sutejo. M dan A.G. Kartasaputra. 1998. Pupuk dan Cara Pemupukan. Jakarta: PT Penebar Sadaya.

Novizan. 2007. Petunjuk Pemupukan yang Efektif. Jakarta: Agromedia Pustaka.

Okalia, D., C. Ezward dan A. Haitami. 2017. Pengaruh Pemberian Dosis Kompos Solid Plus (Kosplus) dalam Memperbaiki Sifat Kimia Tanah di Kabupaten Kuantan Singingi. Jurnal Agroqua 15(1): 8-19. Teluk Kuantan.

Prasetyo, B.H dan D.A. Suriadikarta. 2006. Pengembangan Pertanian Lahan Kering di Indonesia. Jakarta: Jurnal Litbang Pertanian.

Rizwan. M. 2010. Evaluasi Pupuk NPK dan Pupuk Organik Terhadap Pertumbuhan dan Perkembangan Produksi Kacang Tanah. Jurnal Pertanian. Medan: Fakultas Pertanian, Universitas Islam Sumatra Utara.

Sanchez. 1992. Pupuk dan cara pemupukan. Jakarta: Penerbitan Rineka Cipta.

Setiadi. 2008. Bertanam Cabe. Jakarta: Penebar Swadaya.

Sumarno. 1991. Kedelai dan Cara Budidaya. Jakarta: Yasa Guna.

Sunarto. 1997. Kesuburan Tanah dan Pemupukan pada Tanaman Hortikultura. Edisi ke-1. Yogyakarta: Gava Media.

Sutedjo, M.M. 2002. Pupuk dan Cara Pemupukan. Jakarta: Rineka Cipta.

Widjaja, F dan B.N. Utomo,. 2005. Pemanfaatan limbah pengolahan minyak kelapa sawit yang berupa solid untuk pakan ternak (sapi, domba dan ayam potong). Success Story Pengembangan Teknologi Inovatif spesifik Lokasi. Badan Litbang Pertanian. Buku I.hlm.173-185. 